\title{
Place and Role of Norms and Sources of International Law in the Legal System of the Russian Federation: The Doctrinal Exploration and the Legislative Development of the Constitutional Principle
}

\author{
Sergei Yu. Marochkin \\ Institute of Continuing Education, Tyumen State University, Tyumen, Russia. \\ Email: mar@utmn.ru \\ Received April 19 ${ }^{\text {th }}, 2012$; revised May 20 ${ }^{\text {th }}, 2012$; accepted May 28 ${ }^{\text {th }}, 2012$
}

\begin{abstract}
The article introduces one of the aspects of the national legislation and of the Russian doctrine concerning the entire problem - implementation of generally recognized principles and norms of international law (IL) and international treaties as an integral part of the legal system of Russia. It can be interesting for at least two reasons. First, the Constitution of the country establishes the direct application of international obligations in the domestic matters without their incorporation into the legislation. Not many countries go this way. Second, one can say about the whole theory consisting of a complex of aspects elaborated by the Russian doctrine of IL concerning of operation and realization of international norms. Some propositions and conclusions of this theory could be interesting and useful for colleagues in the countries where implementation of IL norms is also based on the principle of their direct application. In particular, the article examines the question of how the constitutional provision on the place and role of international obligations is being interpreted in the theory and developed in the legislation. The situation of the 90's years of the past century and in the first decade of the current century is being compared. It is noted that the practice (especially judicial) moves forward leaving the legislation and legal theory behind in understanding of the constitutional principle's content, what does not conduce to full and precise realization of one of the foundations of the constitutional system of the country.
\end{abstract}

Keywords: Constitution; Constitutional Principle; Generally Recognized Principles and Norms of IL; International Treaties of Russia; Sources of Law; Legislation; Doctrine; Legal Theory; Research-and-Practice Commentaries

\section{Preliminary Observations}

The first appearance in 1993 in the national constitutional development of the principle on universally recognized principles and norms of IL and international treaties of the Russian Federation as part of its legal system has played an outstanding role. The Constitution of 1993 contains quite a radical provision: "The generally recognized principles and norms of international law and the international treaties of the Russian Federation shall be an integral part of its legal system. If an international treaty of the Russian Federation establishes other rules than those provided by the law, the rules of the international treaty shall apply" (Part 4, Article 15). This principle has reflected the desire for greater openness of Russia to the international community, its involvement into European and world structures, into international human rights mechanisms.
Domestically, this rule has become crucial in the context of the legal guarantees of national implementation of Russia's international obligations, a turning point in changing and upgrading of the entire legal system: national law, legal practice and sense of justice. One should especially note that this principle is not an "ordinary" norm of the Constitution. It is included in the Chapter I of the Constitution and together with other principles it forms the fundamentals of the constitutional system of the country. All other norms of domestic law have to correspond to them. The direct use and application of IL fixed at the constitutional level is now one of the main ways to develop judicial practice.

Nowadays, IL is not a "foreign body" in the internal life of the State. It is rather a usual legal tool in the activities of all State organs, citizens, legal entities and organizations, and most of all, of the courts. The ensuring of the action and the application of IL in the national 
jurisdiction via direct implementation by the courts would fit the contemporary dynamics of life, avoiding the long process of incorporation into legislation.

This constitutional provision was included in practically all codes and federal laws adopted after the Constitution. Thus, the current Russian legislation is based on the common principle of and approaches to IL, which remained untypical during the previous socialist period. The former Soviet constitutions did not contain such basic provisions on the interaction between international and national law.

The new approach of the Constitution to IL led to the appearance of many research works in IL (articles, books and doctoral dissertations) of Russian scholars [1-12] based on theory and on practice of IL application and published in Russia and abroad.

It is possible to say that the Russian theory of IL has played and still plays a significant role in the research of the issue of operation and application of IL in the domestic legal system. It elaborated this issue as a complex of aspects: the place and the role of IL norms in domestic jurisdiction, correlation between sources of IL and national law, the hierarchy of internal and international norms, juridical conditions of application of IL norms, methods (the procedure) of determining of applicable (international and/or national) law, etc. [14-18]. Here I should note a direct influence of the IL doctrine on judicial practice. Thus, the Ruling of the Supreme Court Plenum (Board) of the Russian Federation of 10 October 2003 On Application of Generally Recognized Principles and Norms of International Law and the International Treaties of Russia by Courts of General Jurisdiction having an obligatory character, "absorbs" key theoretical aspects mentioned above as a guideline for lower courts. Individual courts' decisions (in particular, of the Constitutional Court of the Russian Federation) often address theoretical propositions.

Hypotheses and conclusions of the Russian IL doctrine might be suitable for or at least considered by researchers and scholars in different countries, which Constitutions say about a direct effect (application) of IL (e.g. the Netherlands). As well as works of colleagues and judges [19-21] demonstrate an experience of those countries in implementation and application of IL.

Due to the direct force and operation of the Constitution the courts in their decisions, the plaintiffs (citizens, legal entities, state bodies) in complaints directly refer to the Constitutional principle on IL for argumentation of their claims and positions. Nonetheless, the principle should be adequately reflected and developed in the branches of the legislation. It also needs a proper exploration and interpretation in the legal theory as well as in particular legal disciplines, especially in ones of constitu- tional and international law.

\section{The Doctrine on the Nature of International Law Norms and Sources in the Domestic Legal Sphere: Stability and/or Conservativity?}

\subsection{IL Norms}

It could seem strange but notwithstanding the fact that since 1993 IL became a legal reality in the domestic legal system and has actually changed the entire legal picture, the legal theory hardly reacted on the altered situation. As a general rule, courses and textbooks on theory of law of the 90s of the last century and the first decade of the present one speak only about the norms of domestic law without consideration and even mentioning IL, or speak just about their differences from each other [22-24].

Despite the specific wording of Article 15 of the Constitution, IL obtains completely different and sometimes unequal status in scientific and academic literature on legal theory and on IL, it is "announced" as a part of domestic law or of the legislation (sometimes authors do it with references to the Constitution that is not correct!) [25-32]. In some cases, it is a principled position (E.T. Usenko, for example, considered irrelevant and mistaken an attitude that the IL norms should be regarded as an integral part of the RF legal system), in other cases such a terminological substitution takes place implicitly and can be hardly explained. Nevertheless in both cases the notion of law (and its integral structure (system)) and the notion of legal system of the country are confused.

IL norms as an expression of agreed wills and positions of States, but not of a will of a sole State, should be interpreted and enforced by all States (including in their domestic affairs) in terms of objects and purposes of IL norms, of IL principles on the whole. This is a clear and generally recognized provision of the law of treaties. Thereby IL norms are hardly grounded to be considered an integral part of the domestic law. They do not change their nature and form; in this sense they are extraneous towards the domestic law norms.

No one domestic act regardless its character and content, which provides fulfilment of a State's international obligations, is not able to alter norms nature, their specific aims, subject-matter, form, etc. That is not even required - the State ensures implementation of the IL norms in particular.

A message occurring in law literature that any norm incorporated into the national legal system shall change its nature and has to be considered by the domestic law subjects as the national law norm, is perceived as a misunderstanding. In any case it is not consistent with the practice of application of IL norms, which shall be inter- 
preted and accepted by courts and other bodies, natural persons and legal entities as norms of other (not domestic) law. Such an approach was emerged in the 90's when after the adoption of the 1993 Constitution the practice of use and application the IL norms started to form.

One of multiple examples is a decision of the Moscow Regional Court of 3 October 1997 in the criminal case against $B$., $L$., and $V$., adopted with regard to the RF Constitutional Court determination on request of the judge of the Moscow Regional Court about a contradicttion of the Criminal Procedure Code to the Constitution and the International Covenant on Civil and Political Rights. In a new trial after vacating of previous judgment by the Presidium of the FR Supreme Court the lawyer referred to the RF Constitutional Court determination which says that in purpose to decide the case it is needed to follow the norm of Part 7 Article 14 of the Covenant "which is to be applied as an IL norm". The Moscow Regional Court held that whereas Part 3 Article 380 of the Criminal Procedure Code contradicts the abovementioned norm of the Covenant, in accordance with Part 4 Article 15 of the RF Constitution "in this case the court is obliged to apply the IL norms" and then decided under Part 7 Article 14 of the Covenant to close the case against the present accused [33].

Further development of the practice has shown that courts followed and keep following this approach as well as they focus Academic Commentaries on codes and federal laws on the same direction.

In particular, the Commentary on the RF Labour Law [34], exemplifying the contents of Article 10 on the role of generally recognized principles and norms of IL and international treaties in the labour relationship regulations, says that this results "in changes of current stereotypes in the Russian legal system and in the legal norms application [...]. It is getting possible and necessary to apply directly the IL norms in case of their ratification by the Russian Federation" (Article 39).

The RF Supreme Court in the "Review on Judicial practice concerning a status of refugee procedure" [35] reflected a current trend, in particular, applying to issues of a family and/or a dependent definition. The Court underlined whereas the Federal Law "On the Refugees" does not include such definitions, courts in judging civil cases "in coordination with the federal law or an international treaty applied the foreign law norms. Herewith if the RF international treaty stated rules not coinciding with those under the law, courts [...] applied the rules of the einternational treaty" (section "Principle of Unity, Family Reunification").

Essentially, this is the function of such a method of international obligations fulfilment, as to refer within the domestic legislation to the IL norms: "The reference is made as far as these norms remain to be norms of that very legal order, which is referred to, they remain to be the same and from the point of view of a referring legal order" [36].

Research of the issue in the national literature produced a burst of wide and long discussion about interacttion of international and soviet (nowadays - Russian) law, about possibility or impossibility of the IL norms acting within the State. This discussion brought its participants apart. Often it was accompanied by a thorough analysis of different points of view and arguments [37-41]. Nevertheless the doctrine of that period up until the adoption of the 1993 Constitution was not either enriched by a common concept or forwarded to an amplification of particular issues in interaction between international and domestic law within the domestic affairs. On the contrary, theoretical constructions were not based on the practice, did not proceed from it and finally did little for it if not darkened its actual aspects. There was no of a wide and systematic study and generalisation of the rule-making and law-enforcement bodies' activity, connected with the reference to IL. The theory and practice had been developing without any touch.

Since 1993, the issues on the role of IL in the legal system of the country began to be discussed not only on the theoretical level-whether it is possible or not for the IL norms to act and to be applied to-but more often on the level of practice. While in the theory they broke a lance, the practice of use and application of the international norms, mostly court practice, got an immense shot in the arm. And the study of the practice shows that a dispute over the nature of the IL norms in the legal system of Russia - whether they stay the same or "transform" into the domestic norms - makes a little difference for the practice itself. The courts refer to particular norms and sources of IL, substantiate cases with their help and award judgements.

In the course of various seminars, symposia and conferences particular issues have been discussed, guides for judges appeared [42-46] reflecting and summarising the practice, and also presenting necessary key points and recommendations.

Rule-making and law-enforcement bodies, all subjects of domestic law, including natural persons and legal entities, employ, refer to and apply the IL norms. Practical guides for judges and commentaries on codes and laws say about not the domestic but IL norms as a manifestation of a State's will in a treaty form. Highest courts do the same when make guiding instructions for lower courts (in Plenum decisions and Informational letters) on employment and application of the IL norms and international treaties in court activity on the whole, and in cases of particular category. Previous (soviet) [40,47-49] and 
current court and arbitration practice bear the same evidence though even now it is heard about "objective boundaries" of IL which are allegedly stable and beyond which its regulating abilities cannot spread: IL acts on the State territory, but not within its internal affairs; it can objectively regulate only State-to-State relations, but not internal relations; interaction means existence of the IL norms and appearance of the corresponding norms in domestic law $[30,50]$.

In changing conditions IL cannot remain as before, all the more in the modern époque of globalization, interdependence, and human rights. Nowadays in the international dialogue not only the States take part, but also nongovernmental bodies that exert a growing influencetransnational corporations, mass media, and NGOs. IL is of great importance in the regulation of rights and for the protection of interests of individuals and legal entities, and is to be directly applied in their legal relations.

The mentioned viewpoint is progressively supported in theory and discovers more substantiation in practice of international courts, in particular, of the European Court of Human Rights (ECtHR) and of the International Court of Justice (ICJ). The Chairman of the ECtHR explicitly speaks about the recognition of an individual as a subject of IL in the European Convention on Human Rights (ECHR). Judge of the ECtHR elected from Russia A.I. Kovler highlights that the Court has reacted quite rigidly on attempts of some national courts to discredit the direct application of the ECHR norms or international legal personality of an individual. V. S. Vereshchetin, formerly Judge at the ICJ, while analysing new trends in the Court activity, pointed out that its recent orders concerned not only the States but the subjects of domestic law as well. For example, in "La Grand (Germany v. United States of America)" case the Court decided that the Vienna Convention on Consular Relations of 1963 regulated the rights and obligations not only of States but also of individuals [51-55].

There is no need to reason upon universal interconnectivity, or steady development and intensification of international relations, or new objects to regulate-this is obvious and generally recognized. But it is not less reasonable or obvious that this process is accompanied by equally active development of the legal systems' interacttion; that the objects regulated by IL and domestic law often coincide; that former traditionally and exclusively "internal affairs" of a State, now fall under the focus not only of domestic law; that supra-national legal regulation is widening; that fundamental principles of IL traditionally considered as the basis for State-to-State relations regulation, now can be also applied to private relations [56-59]. Such trend has been regularly mentioned.

There can be no interdependence of States, tight global links with "objective and subjective boundaries" announced between different legal systems. Who has defined these boundaries and their immutability? It appears that such a brink between the legal systems, their jurisdictions is always conventional and flexible. Thus, one of the statements within this "construction of boundaries" that IL acts on the territory of a State but not within its internal affairs can hardly be understood.

By virtue of its sovereignty a State can spread out functioning of approved and adopted by the State IL norms within the sphere of domestic law to regulate relations between organizations and individuals. The State' will, manifested in other (not legislative but agreement) way, can equally be obligatory within the sphere of domestic jurisdiction by the State approval.

It is worthy of note that the regulation of such kind is often more saving and efficient than "transformation" of the IL norms into domestic ones, or alteration of legislation to correspond with them, for example when domestic law establish one regime for all, whereas the regional or bilateral treaties create a special regime for subjects of particular States (e.g. in passenger, cargo and luggage carriage, or legal assistance, avoidance of double taxation, or retirement insurance, migration, or frontier cooperation, double nationality, etc.). In such treaties it is obvious that they regulate private international and domestic relations, and that their subjects are the participating States as well as subjects of domestic law (individuals, state bodies, legal entities).

A typical example is the Agreement between the Governments of Russia and Estonia On Cooperation in the Sphere of Retirement Insurance of 1993 (came into force on 16 October 2007) [60]. Practically all its articles refer to the parties' competent authorities for assignment of pensions and regulate the types of relevant labour experience, the list of required documents, types of salaries for pension calculation, etc.

Budapest Convention on the Contract for Carriage of Goods by Inland Waterway (CMNI) of 2001 (came into force for Russia in 1 August 2007) [61], concluded for correlation of legal regimes of carriage between the member States of the Central Commission for Navigation on the Rhine and the Danube Commission in cooperation with UNECE, regulates the rights and obligations of the parties under contracts for carriage concerning cargo reception and delivery, liability issues, contract for carriage termination, etc.

Agreement on International Goods Transport by Rail (AIGT) and the Agreement on International Passenger Traffic (AIPT) provide that their provisions are binding for railways, consignors and consignees, and passengers correspondingly.

Over the last years new significant elaborations on 
general issues and on particular branch aspects have been worked out $[6,7,13,16,62-64]$. Nevertheless, it has to be noted an appearance publications of postgraduate students and $\mathrm{PhD}$ candidates (unfortunately even in the respected journals and editions), which often do not go further than abstract theorising, reiteration of generally recognized, conceptual or fundamental theses, reproducetion of earlier expressed opinions and approaches (sometimes without any references to the authors), formulation just additional arguments in favour of one or another theory. Some of such publications sound like a kind of eye-opener as if a problem or an issue has been revealed for the first time ever, has not been earlier discussed and even indicated.

It is also worthy of notice that well-developed in the IL doctrine numerous aspects of applied character of the problem under consideration, which specify key points for the practice, still have not been reflected, or entered into the study literature. Textbooks on IL generally cover a topic on interaction of IL and national law due to the tradition, in the framework of two well-known approaches (monism and dualism) to explanation an issue of correlation of international and domestic law, reproduction of theories, range of arguments, general forms of implementation of the IL norms on the domestic level (transformation, incorporation, legitimating, reception, reference, etc.).

In some textbooks there appear the paragraphs concerning the court practice of IL application, but they mostly consist of sheer description of some or series of cases. However, there is lack of reproduction of a whole set of practically important issues: foundations, legal conditions, order (procedure) of application of the IL norms, correlation of legal power (hierarchy) of the IL and Russian norms. In other words, the particular is given without clarification of the general. In this sense, the textbooks serve aims of general education rather then of training of future specialists and practitioners.

\subsection{IL Sources}

An issue about a place of the IL norms in the legal system of Russia has a logical follow-up: what is a correlation between their forms of explication (sources) and the sources of domestic law, can sources of one law be sources of norms of another law? After all, the Constitution means not only the IL norms as a part of the legal system of the country, but their sources as well-international treaties in particular (see Part 4, Article 15 above, in the first paragraph of Section 1). Taking into account that generally recognized norms often exist in a form of customary IL, it is possible to suggest also such a source as a part of the national legal system.
Legal theory in its traditional "links" with only domestic law does not unfortunately provide definite answer on the question above. And this is typical as to the 90s and to the current decade firstly because a theoretically formulated definition of a source of law has non-general meaning. In one form or another, a source of law is considered to be related to an expression of will of a particular State. This notion is hardly precise even for internal aspect (not all sources of domestic law are expression only of will of a State) and moreover it is not true as regards to sources of IL and interaction of the legal systems. Even such sources as a custom or a precedent the scholars usually mention in a context of domestic law, not meaning IL customs and precedents in the national jurisdiction.

The issue has not changed for the last years: not always international treaties are mentioned when a treaty is described as a source of law [as an exception see: 26,28 , $65,66]$, their place in the legal system of a country is not analysed, not to say about their correlation with internal sources of law. In the works where they are mentioned, assessment of their place in the legal system varies up to polar opposite. In some books they are announced to be a source of law of a country $[26,67,68]$, in another they are featured in a list of sources in general or in a list of sources of law acting in Russia (note, not a source of law of the country, but source acting within it) [69-71]. And only in one case it is precisely and correctly written about a strong necessity to separate consideration and application of sources of domestic law of a particular State and of recognized by the State sources of IL (nearly an exclusive example when the legal theorists involved an international lawyer for elaboration of a textbook on Theory of Law and State) [28].

On the whole, the chapters dedicated to the sources of law do only mention IL in connection with the treaties. As a rule, it is neither meant nor written about significance of norms of customary IL, precedents, doctrine as sources of law being of importance for the legal system of Russia.

In the literature on IL the correlation of sources of international and Russian law has been also evaluated in different ways. A number of researchers consider the sources of IL as one of the types of sources of domestic law. An approach of such kind was spread out before and after the adoption of the 1993 Constitution, though there may be detailed some connotations: "part of legislation", "the law", "source of law of Russia", etc. The present approach can be found nowadays (V. M. Volzhenkina, S. A. Gorshkova, M. M. Boguslavskiy and L. Y. Rykhtikova).

Many international lawyers in the $70-80 \mathrm{~s}$ of the past century, when a dispute on the problem under consideration reached its heights, did not agree to accept the 
sources of IL as the sources of domestic law (G. V. Ignatenko, R. A. Mullerson, A. N. Talalaev). For the last few years this position has been supported by a considerable number of scholars and researchers (P. N. Biryukov, V. A. Tolstik, M. O. Lits, I. V. Fedorov, A. A. Yakovlev, A. V. Lesin, O. V. Sashnikova, A. V. Iliynykh, L. A. Lazutin, B. L. Zimnenko, V. V. Gavrilov and O. I. Rabtsevich).

Strictly speaking, the Constitution does not proclaim treaties to be a source of law of Russia (see Part 4 Article 15). Moreover, having called them a part of the legal system, the Constitution does not insert them at all in the list of sources of domestic law, so placing them aside of the list.

In other words, the sources of IL occupy an independent position within a normative part of the legal system of the Russian Federation, neighbouring the sources of domestic law. They act in association with the latter, but do not integrate into it. The Constitution confirms this position when giving an answer to a logical question about a correlation of legal force (hierarchy) of sources, about a rule of settlement of conflicts between them: a priority of application belongs to an international treaty, if it establishes other rules than the law (Part 4, Article 15).

The court practice expressly and constantly testifies this. As one of examples we can take an abstract from the "Review on Judicial practice concerning a status of refugee procedure" [35], which was elaborated by the RF Supreme Court office for generalisation of the court practice:

"Generalisation of the court practice indicates that not all local migration services while examining requests for a refugee status consider international treaties of the Russian Federation, which under Part 4, Article 15 of the RF Constitution shall apply directly, if they establish other rules than provided by the law".

The Constitution due to its level distinguishes thorough the system of sources of Russian law: it names them; specifies the hierarchy, federal and regional levels among them; conditions of application; correlation with the human rights; particular form of expression of one or another norms or regimes; some rules of procedure in time, space and personality; spheres of federal and regional legislation; responsibility of highest agencies of the State power regarding adaptation and application of normative acts; competence of juridical authorities for legislation enforcement; origins of law-making of the local government.

It's important that in all cases the Constitution understands only those sources which are covered by one-side competence of a State power or a local government, i.e. sources of domestic law properly: the federal laws, the RF presidential decrees, the RF governmental regulations, laws and other normative acts of the Federation subjects (regional level acts), acts of local government.

But the Constitution does not include the sources of IL into this bulk. The latter are mentioned separately and shortly: a general principle of their correlation with the internal sources, as well as a list of issues, which are settled in accord with the IL norms, and some authorities of State bodies in conclusion of treaties.

In development of the Constitution the current legislation, establishing a legal regime in one or another sphere, also separately outlines a role of internal sources (laws, other acts) and external sources (of IL) in process of regulation of particular issues, their correlation (with limited exceptions).

\section{Does the Legislation Favour the Development of the Constitutional Principle on International Law?}

Though the legislation a priori should strictly correspond to the Constitution, it sometimes reveals an interesting variety, which mostly counts against this conformity.

A series of codes and federal laws do not mention at all generally recognized principles and norms of IL (the RF Forest Code, the RF Water Code, the RF Arbitration Procedure Code, the RF Civil Procedure Code, the RF Tax Code, the RF Family Code, federal laws on housing saving co-operative, on land tenure, on peasant farm enterprise, on mass media).

The RF Criminal Procedure Code (Part 3 Article 1), the Federal Constitutional Law On Referendum of the Russian Federation (Part 1 Article 3) indicate the IL norms and treaties as an integral part of the RF legislation. Some acts make mention of them in articles devoted to a structure of legislation in a certain sphere (e.g. Article 1.1 of the RF Administrative Violation Code, Article 3 of the Federal Law On Enforcement Proceedings, Article 4 of the Federal Law On Technical Regulation, the Federal Law On the RF Citizenship). This approach itself predetermines not adequate (non-true) evaluation of their place in the legal system.

A number of codes considerably narrow their role and significance, proclaimed by the Constitution. So, the RF Criminal Code (Article 1) and the RF Administrative Violation Code (Article 1.1) just "rely on" the generally recognized principles and norms of IL. The RF Penal Execution Code (PEC) "proceeds" from a strict adherence of guarantees of defence from attempts and violence "in compliance with" the present norms (Article 3). In all cases generally recognized principles and norms seem to be not a constituent part of the legal system, but its supplement or a foundation for legislation.

Article 3 Penal Execution Legislation of the RF and 
International-Legal Acts of the PEC RF qualifies as the latter all international treaties, and generally recognized principles and norms, and recommendations (declarations) of the international organisations. At the same time this legislation just "recognizes" international treaties concerning execution of sentences (Part 1, Article 3).

As a rare example of a full and correct reflection of a constitutional Part 4, Article 15 in a certain sphere of the legislation may be named the Civil Code (Article 7), the Labour Code (Article 10), the Customs Code (Article 8) of the Russian Federation, as well as federal laws on Order of Consideration of the RF Citizens Applications, on Social Control of Human Rights Security in Places of Forced Imprisonment and on Assistance for People in Places of Forced Imprisonment, etc. The related articles are also properly named: "legal regulation", "legal basis" in an according sphere.

Thus, in accord with Article 1 of the Federal Law On Counter-Terrorism (as amended 30 December 2008) [72] "a legal basis for counter-terrorism consists of the Constitution of the RF, generally recognized principles and norms of international law, international treaties of the RF, the present Federal Law and other federal laws, normative acts of the RF President, normative acts of the RF Government, and also adopted in conformity with them normative legal acts of other federal authorities of the State power".

As in case with the generally recognized principles and norms, the legislation differently accepts the constitutional principle in connection with the IL sources as well. Surprisingly seldom it is made properly, for instance in the Civil, Labour, Customs Codes of the RF.

A series of codes though reproduce only a part of the constitutional principle - concerning a priority of application of international treaties before a particular code and other normative acts of a certain branch (the RF Civil Procedure Code, the Family Code, the Tax Code, the Arbitration Procedure Code).

The others even corrupt the principle to some particular extends. The RF Criminal Procedure Code, for example, declares treaties a constituent part of the RF legislation (Part 3 Article 1), but not of the legal system as it does the Constitution. Obviously, it changes completely a place and role of the treaties than it is stated by the Constitution. It seems logical to have not precise commentaries about a role of the treaties in the criminal court proceedings regulation.

The RF Administrative Violation Code (Part 2 Article 1.1) just "relies" on the international treaties and the RF Criminal Code (Part 2 Article 1) - on the generally recognized principles and norms and totally excludes any notes of IL sources. The Penal Execution Legislation (Part 1 Article 3 of the PEC RF) just "considers" the in- ternational treaties. Finally concerning these branches the international treaties seem not to be a constituent part not only of the legal system, but even the legislation.

\section{The Role of Academic Commentaries on Codes and Federal Laws}

Possibly a very specific feature of the Russian legal system is academic (in Russia they are usually called "research-and-practice") commentaries to the RF Constitution, codes, and federal laws. They form a solid layer of a doctrinal thought and to be written by scholars and researchers and by lawyers and judges as well. Commentaries are also a direct link between a pure theory and legislation, on the one hand, and practice, on the other hand. They are used by the subjects of law and (what is important) by the law-enforcement bodies (including prosecutor's offices and courts) as a ready-to-use practical guides, and in this sense they mostly define a vector of development of law application, justice in particular. That is why among all kinds and forms of theoretical writings it is commentaries that are logically expected to proper interpreting and explaining a constitutional principle in Part 4 Article 15 and related articles in codes and laws, and to make recommendations as well.

Nevertheless unfortunately, commentaries in general do not mark precise key points, or proper full explanation of the articles concerning a role of IL in a related sphere of regulation. Partially it can be explained that such articles are commented by not experts in IL affairs, and for them it is difficult to make a proper comment operating with non-familiar matters and terminology. This fact might be understood and accepted.

But the problem yet is in the point that it is specific for commentaries to pay poor attention to the text of the Constitution, a commented code or law, and also a confusion in terminology (a norm, a source, a treaty, a system of law and a legal system).

On the whole, the commentaries are of little use for practitioners, they do not define a role and place of the IL norms in the legal system and at its best they nearly word-for-word reproduce the text of a particular article or circle the international sources, where there may be found generally recognized principles and norms (the Charter of the United Nations, the Universal Declaration of Human Rights, the Resolutions of the General Assembly, ILO Conventions, etc.).

The authors of the Commentary on the RF Labour Code [73], for instance, "helped" the users only by saying that "Unfortunately, such principles are not defined in compliance with the labour legislation of Russia. This makes it hardly possible to designate a set of international principles of the labour law, which are a constitu- 
ent part of a system of the Russian labour law". Logically to ask what is the role of the doctrine and such commentaries?

Some authors do not only give an extensive explication of particular articles, but do not even differentiate the acts (sources) and norms. Commentary on the RF PEC following Article 3 The Penal Execution Legislation of the RF and International Legal Acts while explaining its provisions used the notions "acts" and "generally recognized principles and norms" as exchangeable. At the same time authors of the Rostov commentary on the RF Constitution all in one paragraph associated treaties with the IL norms and vice versa referred to such norms as to international documents $[74,75]$.

Humble attempts of the commentaries authors to define a place of the IL norms in the legal system of Russia are not correct enough. So, the Commentary on the RF Labour Code explains that "international law norms shall be incorporated into the Russian legislation, into the structure of particular laws", and that the international principles of the labour law are "a constituent part of the Russian labour law" [67-73].

Even the commentaries on the Constitution itself in explaining Part 4 Article 15 usually do not define a place and a role of the IL sources within the legal system. Repeating the phrase "shall be a constituent part of the legal system", they do not even try to explicate and reveal the meaning, or see it only in "to legally fix a priority of IL origins and decisions (?!-S. M.) in a hierarchy of the internal sources of the State"[76-80] (as it was done by a group of analysts from the Institute of Legislation and Comparative Legal Studies at the RF Government). A regulation on priority of treaties over laws is just reiterated or given a poor clarification. And again a question about practicability of such commentaries arises.

Simple reproduction of articles without any explanation or revealing their meaning is very characteristic for most commentaries on codes and law [81-85]. Obviously, it is senseless to expect the other from the commentaries to acts, which narrow or distort the meaning of a constitutional principle: each of them explains a particular code or law, thus more or less being kept within the frames of the latter. But this is also peculiar for those which adequately and fully reproduce a constitutional provision (the Civil, Labour, and Customs Codes of the RF).

In some commentaries the authors as if tried to recreate a context of a constitutional principle omitted in a code (e.g. the RF Arbitration Procedure Code, the RF Civil Procedure Code, the RF Tax Code do not mention generally recognized principles and norms of IL). But this is it-with this they do not try to reveal or explicate the meaning of regulations under consideration, to designate a role and a place of the IL sources in the legal system of Russia [86-93]. In those places where codes or laws distort a constitutional norm, commentaries have to "correct" them. Some commentaries on the RF Criminal Procedure Code [94-96], for example, carefully get readers back to the initial regulation of the Constitution.

Finally, a series of commentaries declare the IL sources to be a part of domestic law or the legislation [97-100]. By negligence or other cause, this "substitution" (a part of not a legal system but of legislation) in principle alters the meaning of the constitutional provision. As it was mentioned above, the IL norms do not pour into the bulk of the domestic law norms, they act and apply in the legal system of Russia together with latter, remaining a part of IL. Consequently, forms of their existence (sources) cannot become sources of domestic law.

As a result, quite full, developed commentaries unpacking the notion of generally recognized principles and norms, defining a place and a role of IL in the legal system of Russia on the whole and in compliance with its components are unfortunately rare. In this respect the commentary, which (as an exception) was written by a group of analysts involving an international lawyer, stands prominently out [101-103].

\section{Conclusions}

Study of the issue proves a presence of an obvious diversity in a level of reflection and realization of the constitutional principle on international component of the Russian legal system within the legislation and its exploration in theory (including research-and-practice commentaries on codes and laws), on the one side, and comprehension and development of this principle in practice, in court activity first of all, on the other side. With obvious contradictions and defects in legislation and doctrine the current situation in practice significantly differs. Application of this principle and, on its basis, international norms and documents has become habitual and routine in court activity. The courts have not only familiarised but significantly detailed and developed its contents [104]. The practice (especially judicial) moves forward leaving the legislation and the doctrine behind in understanding of the constitutional principle's content. Such a disparity does not conduce to full and precise realization of one of the foundations of the constitutional order of the country.

Crucial for practice conclusions supervene on provision that the IL norms in the process of their operation in the legal system of the Russian Federation do not become domestic legal norms, and the IL sources do not become sources of Russian law. Norms and sources of IL occupy an isolated position in the normative corpus of the legal system of the Russian Federation, and function along with Russian law. They have to be explained and applied 
in accord with aims and principles of IL and a certain treaty, as provided for herein temporal, special and subjective limits of application, in context of herein used terms, but not from the angle of any correlated key points of domestic law.

This aim is targeted by international treaties, and primarily a core document for IL of treaties - the Vienna Convention on the Law of Treaties of 1969, and also the majority of literary sources and the court practice.

Here we come to another conclusion: sources of IL within the legal system of the Russian Federation stay apart from sources of domestic law on their legal force (hierarchy) as well [105].

\section{REFERENCES}

[1] A. N. Talalaev, "Correlation of International and Domestic Law and the Constitution of the Russian Federation," Moscow Journal of International Law, No. 4, 1994, p. 3.

[2] O. N. Khlestov, "International Law and Russia," Moscow Journal of International Law, No. 4, 1994, p. 15.

[3] I. I. Lukashuk, "Constitution of Russia and International Law," Moscow Journal of International Law, No. 2, 1995, p. 29.

[4] E. T. Usenko, "Correlation and Relationship of International and Domestic Law and the Russian Constitution," Moscow Journal of International Law, No. 2, 1995, p. 13.

[5] G. M. Danilenko, "The Path to the 'Kingdom of Law and Justice," Moscow Journal of International Law, No. 1, 1997, p. 82.

[6] P. N. Biryukov, "Norms of International Criminal Procedure Law in the Legal System of the Russian Federation," Istoki, Voronezh, 2000.

[7] V. V. Gavrilov, "Notion and Interaction of International and National Legal Systems," Dalnevostochny University Press, Vladivostok, 2005.

[8] A. L. Burkov, "Convention on Protection of Human Rights in Russian Courts," Walters Kluwer, Moscow, 2011.

[9] V. S. Vereshchetin, "New Constitutions and the Old Problem of the Relationship between International Law and National Law," European Journal of International Law, Vol. 7, No. 1, 1996, pp. 29-41. doi:10.1093/oxfordjournals.ejil.a015502

[10] G. M. Danilenko, "Implementation of International Law in Russia and other CIS States," Wayne State University School of Law, 1998.

[11] B. R. Tuzmukhamedov, "International Law in the Russian Constitutional Court," Proceedings of the 94th Annual Meeting of the American Society of International Law, April 2000, p. 166.

[12] S. Yu. Marochkin, "International Law in the Courts of the Russian Federation: Practice of Application," Chinese Journal of International Law, Vol. 6, No. 2, 2007, pp. 329-344.
[13] W. Butler, "Russian Federation," In: D. Sloss, Ed., The Role of Domestic Courts in Treaty Enforcement: A Comparative Study, CUP, 2009, pp. 410-447. doi:10.1017/CBO9780511635458.011

[14] I. I. Lukashuk, "Norms of International Law in the Legal System of Russia," Spark, Moscow, 1997.

[15] S. Yu. Marochkin, "Action of International Law Norms in the Legal System of the Russian Federation," Tyumen State University Press, Tyumen, 1998.

[16] S. Yu. Marochkin, "Operation and Realization of International Law Norms in the Legal System of the Russian Federation," Norma, Moscow, 2011.

[17] V. A. Tolstik, "Hierarchy of Russian and International Law," Yurait, Moscow, 2001.

[18] B. L. Zimnenko, "International Law and the Russian Legal System,” EIP, Utrecht, 2007.

[19] A. Nollkaemper, "National Courts and the International Rule of Law," Oxford University Press, 2011, pp. 117 213. doi:10.1093/acprof:oso/9780199236671.003.0006

[20] A. Nollkaemper, "The Netherlands," In: D. Sloss, Ed., The Role of Domestic Courts in Treaty Enforcement: A Comparative Study, Cambridge University Press, Cambridge, 2009, pp. 326-369. doi:10.1017/CBO9780511635458.009

[21] T. de Vries, "The Role of International Courts in the Dutch Legal System," International Law, No. 1, 2011, p. 18.

[22] A. A. Polyakov, "General Theory of Law. Issues of Interpretation in the Context of Communicative Approach. Series of Lectures," ID Yuridicheskaya, Saint Peterburg, 2004, pp. 693-743.

[23] V. M. Syrykh, "Theory of State and Law. Course Book," Delo, Moscow, 2007.

[24] V. N. Khropanyuk, "Theory of State and Law. Course Book," Yurizdat, Moscow, 2008.

[25] V. S. Nersesyants, "General Theory of State and Law. Course Book," Nauka, Moscow, 2001.

[26] A. F. Cherdantsev, "Theory of State and Law. Course Book," Prospect, Moscow, 2001.

[27] M. N. Marchenko, "General Theory of State and Law. Academic Course," Statut, Moscow, 2001.

[28] V. D. Perevalov, "Theory of State and Law. Course Book," Yurait, Moscow, 2008.

[29] N. I. Matuzov and A. V. Mal'ko, "Theory of State and Law. Series of Lectures," Yuridicheskaya Literatura, Moscow, 2001.

[30] E. T. Usenko, "Essay on Theory of International Law," Norma, Moscow, 2008.

[31] A. B. Vengerov, "Theory of State and Law. Course Book," Yurist, Moscow, 2008.

[32] M. N. Marchenko, "Problems of Theory of State and Law," Gardariki, Moscow, 2002.

[33] "Herald of the Constitutional Court of the Russian Federation," No. 1, 1998, pp. 47-51.

[34] A. L. Safonov, "Commentary of Official Authorities on 
the RF Labour Code,” Profizdat, Moscow, 2006.

[35] Database, "Consultant Plus. Version Prof Legislation."

[36] D. Anzilotti, “Course of International Law," Progress, Moscow, 1961.

[37] A. S. Gaverdovskiy, "Implementation of the International Law Norms," Nauka, Kiev, 1980.

[38] G. V. Ignatenko, "Interrelation of Domestic and International Law. Study Guide," Sverdlovsky Yuridicheskyi Institute, Sverdlovsk, 1981.

[39] V. G. Butkevich, "Correlation between Domestic and International Law," Naukova Dumka, Kiev, 1981.

[40] R. A. Mullerson, "Correlation between International and National Law," Mezhdunarodnye Otnosheniya, Moscow, 1982.

[41] R. A. Mullerson and G. I. Tunkin, "Course of International Law,” Progress, Moscow, 1989.

[42] "On Application of the International Law Norms by the Law-Enforcement Bodies of the Russian Federation: Review of Proceedings of the Research-and-Practice Conference," State and Law, No. 5, 1996.

[43] "First Research-and-Practice Conference on Issues of Application of the International Law Norms by the Russian Federation Law-enforcement Agencies," Moscow, 7-9 February 1996.

[44] "Russian Legal System and International Law: Current Issues of Interrelation: Proceedings of the All-Russia Research-and-Practice Conference," State and Law, No. 2-4, 1996.

[45] M.A. Mityukov and S.V. Kabishev, "Generally Recognized Principles and Norms of International law, International Treaties in Practice of the Constitutional Justice," Proceedings of the All-Russia Meeting, Moscow, 24 December 2004.

[46] B. L. Zimnenko, "On Application of International Law Norms by Courts of General Jurisdiction. Reference Guide," Statut, Moscow, 2005.

[47] S. Yu. Marochkin, "Legal Foundations and Practice of Court Application of the International Treaties in the Civil Cases Disposal," In: G.V. Ignatenko, Ed., International Treaties Implementation in the USSR. Issues of Theory and Practice, Sverdlovsk, 1986, pp. 88-95.

[48] S. Yu. Marochkin, "Implementation of the International Treaties' Norms in the USSR: To Development of the Issue," In: G.V. Ignatenko, Ed., Problems of the International Law Norms Realization, Sverdlovsk, 1989, pp. 411.

[49] S. Yu. Marochkin, "Improvement of Civil-Law Procedure with Participation of Foreign Citizens," In: S.V. Nikitin, Ed., Court-Legal Reform and Increase of Justice Effectiveness, Tyumen, 1991, pp. 36-43.

[50] S. V. Chernichenko, "Question of Correlation between International and Domestic Law as Legal Systems (Reflections on Some Books of Colleagues)," Jurisprudence, No. 1, 2009, pp. 21-24, 28.

[51] A. I. Kovler, "Issues of the International Law in Decisions of the European Court on Human Rights (Interna- tional Legal Personality and State Immunity," Russian Yearbook of International Law, 2003, pp. 299-306.

[52] A. I. Kovler, “Anthropology of Law. Course Book," Yurist, Moscow, 2002.

[53] V. S. Vereshchetin, "Some Aspects of Correlation of International and National Law in Practice of the UN International Court of Justice," Russian Juridical Journal, No. 3, 2002, pp. 19-26.

[54] V. S. Vereshchetin, "The UN International Court of Justice on a New Stage," Russian Yearbook of InternationalLaw, 2006, pp. 16-18.

[55] R. A. Mullerson, "Ordering Anarchy. International Law in International Society," Martinus Nijhoff Publishers, London, 2000.

[56] Yu. A. Tikhomirov, "Globalization: Interdependence of Domestic and International Law," Journal of Russian Law, No. 11, 2002, p. 5.

[57] M. M. Boguslavskiy, "International Private Law. Course Book," Yurist, Moscow, 2009, p. 56.

[58] K. Jauffret-Spinosi, "Issues and Development Perspectives of the Legal Cooperation in the Framework of the Chankhai Organization of Cooperation, European-Asian Economic Cooperation and Partnership with EC: Speech at the European-Asian Law Congress," Russian Juridical Journal, No. 5, 2009, pp. 22-25.

[59] T. N. Neshataeva, "Court and Generally Recognized Principles and Norms of International Law," Herald of the Supreme Arbitrazh Court of the RF, No. 3, 2004, pp. 124 140.

[60] Bulleten' mezhdunarodnykh dogovorov, "Bulletin of International Treaties," No. 3, 2008.

[61] Sobraniye zakonodatel'stva RF, "Compilation of Legislation of the Russian Federation," No. 44, 2007.

[62] S. V. Polenina, "Gender Equality. Issue of Equal Rights and Equal Abilities of Men and Women," Gardariki, Moscow, 2005

[63] V. M. Volzhenkina, "The International Law Norms in Russian Criminal Procedure," ID Yuridicheskaya, Saint Peterburg, 2001.

[64] O. I. Rabtsevich, "Right for a Fair Trial: International and Domestic Regulation," Yurait, Moscow, 2005.

[65] V. V. Lazarev, "Theory of State and Law. Course Book," Prospect, Moscow, 2001.

[66] M. N. Marchenko, "Theory of State and Law. Course Book," Statut, Moscow, 2007

[67] M. M. Rassolov, V.O. Luchin and B.S. Ebzeev, "Theory of State and Law. Course Book," Infra-M, Moscow, 2000.

[68] M. N. Marchenko, "International Treaty as a Source of Current Russian Law," Herald of the Moscow University. Series 11 "Law", No. 3, 2004, pp. 3-18.

[69] V. V. Lazarev, "General Theory of State and Law. Course Book," Omega-L, Moscow, 2002.

[70] A. B. Vengerov, "Theory of State and Law. Course Book," Prospect, Moscow, 2005. 
[71] L. A. Morozova, "Theory of State and Law. Course Book," Yurizdat, Moscow, 2008.

[72] Compilation of Legislation of the Russian Federation, No. 11, 2006.

[73] M. O. Buyanova and I.A. Kostyan, "Commentary on the RF Labour Code,” Profizdat, Moscow, 2007.

[74] A. S. Mikhlin, "Commentary on the Penal Execution Code," Norma, Moscow, 2008.

[75] Yu. M. Prusakov, "The RF Constitution. Research-andPractice Commentary," Yurlitinform, Moscow, 2001.

[76] G. D. Sadovnikova, "Commentary on the RF Constitution," TK Velbi, Moscow, 2001.

[77] V. D. Karpovich, "Paragraph-to-Paragraph Commentary on the RF Constitution," Yurtsentr Press, Moscow, 2002.

[78] V. V. Lazarev, "Research-and-Practice Commentary on the RF Constitution," Yurist, Moscow, 2003.

[79] O. E. Kutafin, "Paragraph-to-Paragraph Research-andPractice Commentary on the RF Constitution," Statut, Moscow, 2003.

[80] E. Yu. Barkhatova, "Commentary on the RF Constitution," Yurait, Moscow, 2008.

[81] E. N. Sidorenko, "Commentary on the RF Administrative Violation Code," Omega-L, Moscow, 2003.

[82] V. E. Sevryugin, "The RF Administrative Violation Code. Research-and-Practice Commentary," Yurist, Moscow, 2004.

[83] E. N. Renov, "Commentary on the RF Administrative Violation Code," Prospect, Moscow, 2004.

[84] V. I. Seliverstov, "Commentary on the RF Penal Execution Code," Gardariki, Moscow, 2008.

[85] A. N. Guev, "Paragraph-to-Paragraph Commentary on the RF Tax Code. Part 1," Infra-M, Moscow, 2005.

[86] V. M. Lebedev and Y. I. Skuratov, "Commentary on the RF Criminal Code," Yurizdat, Moscow, 2002.

[87] V. I. Radchenko, "Commentary on the RF Civil Procedure Code," TK Velbi, Moscow, 2003.

[88] L. M. Pchelintseva, "Commentary on the RF Family Code," Yurlitinform, Moscow, 2006.

[89] A. N. Guev, "Paragraph-to-Paragraph Commentary on the RF Customs Code," Omega-L, Moscow, 2004.

[90] Yu. F. Kvasha, "Commentary on the RF Tax Code, Part I, II,” Walters Kluwer, Moscow, 2007.
[91] G. A. Zhilin, "Commentary on the RF Arbitrate Procedure Code (Paragraph-to-Paragraph)," Yurait, Moscow, 2007.

[92] V. V. Yarkov, "Commentary on the RF Arbitrate Procedure Code (Paragraph-to-Paragraph)," Yurist, Moscow, 2003.

[93] G. A. Zhilin, "Commentary on the RF Civil Procedure Code (Paragraph-to-Paragraph),” Norma, Moscow, 2006.

[94] A. B. Borisov, "Commentaries on the RF Criminal Procedure Code with Practical Explanations and Paragraphto-Paragraph Materials," ID Yurisprudentsia, Moscow, 2007.

[95] I. L. Petrukhin, "Commentary on the RF Criminal Procedure Code (Paragraph-to-Paragraph)," Infra-M, Moscow, 2000.

[96] V. V. Mozyakov, "Commentary on the RF Criminal Procedure Code," Delo, Moscow, 2002.

[97] P. V. Krasheninnikov, "Paragraph-to-Paragraph Commentary on the RF Civil Procedure Code," Statut, Moscow, 2003

[98] A. B. Borisov, "Commentary on the RF Civil Code," Yurizdat, Moscow, 2005.

[99] E. L. Danilov, "Civil Procedure Code of the RF. Commentaries. Paragraph-to-Paragraph materials. Court and Law Practice. Samples,” TK Velbi, Moscow, 2005.

[100] A. V. Nikiforov, "Commentary on the RF Civil Procedure Code," Yurlitinform, Moscow, 2006

[101]B. N. Topornin, "The RF Constitution. Research-andPractice Commentary,” Prospect, Moscow, 1997.

[102] O. N. Sadikov, "Commentary on the RF Civil Code, Part I," Gardariki, Moscow, 2005.

[103] V. D. Zor'kin and L. V. Lazarev, "Commentary on the RF Constitution," Yuridicheskaya Literatura, Moscow, 2009.

[104] S. Yu. Marochkin, "On International Component of the Russian Legal System: Exploration and Development of a Constitutional Principle by Means of Practice," Jurisprudence, No. 1, 2010, p. 160.

[105] S. Iu. Marochkin, "Correlation of International Law and Russian Law," East European and Russian Yearbook of International and Comparative Law, Vol. 4-5, 2010-2011, p. 111. 